Article

\title{
Anti-Phototoxicity Effect of Phenolic Compounds from Acetone Extract of Entada phaseoloides Leaves via Activation of COX-2 and iNOS in Human Epidermal Keratinocytes
}

\author{
Yanisa Mittraphab ${ }^{1}$, Yhiya Amen ${ }^{1,2} \mathbb{D}$, Maki Nagata ${ }^{1}$, Masako Matsumoto ${ }^{1}$, Dongmei Wang ${ }^{1}$ \\ and Kuniyoshi Shimizu ${ }^{1, *}$
}

1 Division of Systematic Forest and Forest Products Sciences, Department of Agro-Environmental Sciences, Graduate School of Bioenvironmental Sciences, Kyushu University, Fukuoka 819-0395, Japan; yanisa.mitt@gmail.com (Y.M.); yhiyaamen@gmail.com (Y.A.); makinagata0817@gmail.com (M.N.); mandm8010@hotmail.com (M.M.); spswdm@hotmail.com (D.W.)

2 Department of Pharmacognosy, Faculty of Pharmacy, Mansoura University, Mansoura 35516, Egypt

* Correspondence: shimizu@agr.kyushu-u.ac.jp; Tel.: +81-92-802-4675

check for updates

Citation: Mittraphab, Y.; Amen, Y.; Nagata, M.; Matsumoto, M.; Wang, D.; Shimizu, K. Anti-Phototoxicity Effect of Phenolic Compounds from Acetone Extract of Entada phaseoloides Leaves via Activation of COX-2 and iNOS in Human Epidermal

Keratinocytes. Molecules 2022, 27, 440 . https: / / doi.org/10.3390/

molecules 27020440

Academic Editors: Mansour Sobeh, Mona F. Mahmoud and Daria Maria Monti

Received: 23 December 2021

Accepted: 7 January 2022

Published: 10 January 2022

Publisher's Note: MDPI stays neutral with regard to jurisdictional claims in published maps and institutional affiliations.

Copyright: (C) 2022 by the authors. Licensee MDPI, Basel, Switzerland. This article is an open access article distributed under the terms and conditions of the Creative Commons Attribution (CC BY) license (https:// creativecommons.org/licenses/by/ $4.0 /)$.

\begin{abstract}
The extract from Entada phaseoloides was employed as active ingredients of natural origin into cosmetic products, while the components analysis was barely reported. Using LC-DADMS/qTOF analysis, eleven compounds (1-11) were proposed or identified from acetone extract of E. phaseoloides leaves (AE). Among them, six phenolic compounds, protocatechuic acid (2), 4-hydroxybenzoic acid (3), luteolin-7-O- $\beta$-D-glucoside (5), cirsimaritin (6), dihydrokaempferol (9), and apigenin (10), were isolated by various chromatographic techniques. Protocatechuic acid (2), epicatechin (4), and kaempferol (11) at a concentration $100 \mu \mathrm{M}$ increased the HaCaT cells viability of the UVB-irradiated cell without any cytotoxicity effect and reduced the expression of COX-2 and iNOS inflammation gene. Moreover, compounds 2 and 4 could have potent effects on cell migration during wound closure. These results suggest that compounds 2, 4, and 11 from AE have anti-photoaging properties and could be employed in pharmaceutical and cosmeceutical products.
\end{abstract}

Keywords: Entada phaseoloides; photoprotection; UVB; HaCaT cells; cosmeceuticals

\section{Introduction}

Entada phaseoloides (Family: Fabaceae) is a huge evergreen that grows high in the tropical forest and is found in Africa, Asia, and Australia's lowland coastal forests. The pods become large in length and width $(2 \mathrm{~m}$ and $130 \mathrm{~mm}$, respectively). The brown seeds (around 10-20 seeds) are contained inside, with a diameter size of approximately up to 100. In Southeast Asia and tropical regions, E. phaseoloides is a well-known traditional medicinal plant. It has been claimed that E. phaseoloides is used as folk therapy for a variety of diseases and has a wide range of therapeutic characteristics. People in tropical and sub-tropical regions use almost all portions of this plant in traditional medicine to treat a wide range of diseases, including hemorrhoids, stomachaches, toothaches, spasms, gastritis, and lymphadenitis [1]. The components and biological activities (such as anti-inflammatory activity and antioxidant) of the seeds and stems of E. phaseoloides were investigated. In 1989, the first report, E. phaseoloides leaves yielded entadamide C, a Sulphur-containing amide that was isolated and described [2]. Few data are available on compounds isolated from $E$. phaseoloides leaves. The isolated compounds from E. phaseoloides seeds and stems such as quercetin, luteolin, apigenin, and dihydrokaempferol have been reported [3]. Flavonoids have been linked to a wide range of biological activities, including illness prevention, therapy, and prevention of coronary heart disease, neurological diseases, and more [4]. Entadine ${ }^{\circledR}$ is a photo-aging agent that shields the skin from both sun and indoor radiation. It is a skin-care ingredient derived from the seeds and stems of E. phaseoloides. 
The human skin is the body's most exposed organ and defends against a variety of environmental ailments. Meanwhile, chronic, and recurrent environmental harm to human skin is a real possibility. UV radiation from the sun is a type of high-energy electromagnetic radiation that is regarded to be phototoxic to all organisms. UV radiation can be divided in three types based on the wavelengths: UVA (315-400 nm), UVB (280-315 nm), and UVC (200-280 nm). The ozone layer in the atmosphere absorbs UVC. UVA and UVB radiation reach the ground in about $95 \%$ and $5 \%$ of cases, respectively [5]. UV light induces programmed cell death, or apoptosis, which is an important preventive mechanism for the skin against neoplastic transformation [6]. The UVB, a large part of the solar UV, is ineffective in penetrating into the deep skin layer; however, it particularly influences the epidermis (the skin's superficial layer which mostly comprises of keratinocytes) [7]. The reactive oxygen species (ROS), such as peroxyl radicals, hydroxyl radicals, active precursors so-called singlet oxygen and superoxide radicals, such ROS could attack cellular organelles as well as cells membrane causing not only the damage in organelle but also lipid peroxidation. There are three consequences of UVB irradiation of HaCaT. Firstly, the growth of post-irradiation-dependent in ROS, secondly, decline of subsequent cell membrane fluidity, and lastly, the mitochondrial membrane depolarization. Moreover, solar radiation is one of the important factors potentially causing skin diseases and specialized epithelium [8]. Consequently, they decrease intracellular ROS levels that might be the powerful strategy for the protection of skin damage. Over the past years, the development of natural compounds and flavonoids (can be generally found in fruits, vegetables, green tea, red wine, and a variety of biological activities like antioxidation) have significantly drawn attention as preventive agents for fighting UVB-induced skin damage via scavenging $\operatorname{ROS}[9,10]$.

Our investigation: the protective effect of acetone extract from E. phaseoloides leaves (AE) on UVB-irradiated HaCaT cells. However, the active compounds from AE are not unknown. Currently, we isolated the components and investigated the protective effect of UVB-irradiated on HaCaT cells.

\section{Material and Methods}

\subsection{Chemicals and Reagents}

The solvents, $n$-hexane, dichloromethane (DCM), ethyl acetate (EtOAc), acetone, and methanol $(\mathrm{MeOH})$, were purchased from Wako Pure Chemical Industries (Osaka, Japan). The standard compounds, epicatechin, gallic acid, and 4-hydroxybenzoic acid, were purchased from Wako Pure Chemical Industries (Osaka, Japan). Quercetin and luteolin were purchased from Sigma-Aldrich (St. Louis, MO, USA). Apigenin, protocatechuic acid, and kaempferol were purchased from Tokyo Chemical Industry (Tokyo, Japan).

\subsection{Identification of the Isolated Compounds}

${ }^{1} \mathrm{H}$ and ${ }^{13} \mathrm{C}-\mathrm{NMR}$ spectra were recorded using a Bruker DRX-600 spectrometer (Bruker Daltonics, Billerica MA, USA); methanol- $d_{4}\left(\mathrm{CD}_{3} \mathrm{OD}-d_{4}\right)$ and chloroform- $d\left(\mathrm{CDCl}_{3}-d\right)$ were purchased from Cambridge Isotope Laboratories (Andover, MA, USA). Analytical TLC was carried out on silica gel $60 \mathrm{~F}_{254}$ plate (Merck, Darmstadt, Germany) using $\mathrm{H}_{2} \mathrm{SO}_{4}$ in methanol, followed by heating. Preparative TLC was performed on silica gel (Merck, Darmstadt, Germany).

\subsection{Extraction and Isolation}

Leaves of E. phaseoloides were collected from Kanchanaburi Province, Thailand, in June 2019 and authenticated by Ratanachai Suthima, a staff of Forestry Center in Kanchanaburi. The sample was dried under the shade for four days and then ground into a fine powder. The powdered E. phaseoloides leaves (200 g) was extracted by sonicator bath at $50{ }^{\circ} \mathrm{C}$ with acetone four times $(4 \mathrm{~L}, 60 \mathrm{~min}$ each). Acetone extract was evaporated under reduced pressure, using a rotary vacuum evaporator at $45^{\circ} \mathrm{C}$ to give acetone crude extract $(9.529 \mathrm{~g})$. Acetone crude extract was analyzed by HPLC and chromatogram. The 
acetone extract $(9.592 \mathrm{~g}$ ) was chromatographed over a silica gel (Wakogel C 200, pore size $7 \mathrm{~nm}$, particle diameter $75-15 \mu \mathrm{m}$ ) column with gradient EtOAc: $n$-hexane mixture to afford 27 subfractions (EPL1-EPL27). Fraction EPL21 was purified again by preparative TLC (acetone- $n$-hexane, 3:7 $v / v)$ to give $9(0.62 \mathrm{mg})$. Fraction EPL22 was fractionated by silica gel column chromatography eluted with acetone- $n$-hexane (1:9 to 1:0 $v / v)$ mixture to obtained $3(6.01 \mathrm{mg})$. Fraction EPL23 was purified by chromatographic techniques to afford $3(2.97 \mathrm{mg}), \mathbf{9}(7.61 \mathrm{mg}), \mathbf{6}(0.55 \mathrm{mg})$, and $\mathbf{1 0}(1.32 \mathrm{mg})$. Fraction EPL24 was isolated by chromatographic techniques to give $2(12.11 \mathrm{mg})$. Fraction EPL 27 was fractionated by normal phase MPLC (BUCHI, Reverelis Prep Purification System, Switzerland), then subjected to reverse phase MPLC system to afford 5 (6.88 $\mathrm{mg})$.

\subsection{High-Performance Liquid Chromatography (HPLC) Analysis}

All experiments were performed on a 1260 infinity II LC (Agilent Technologies, Santa Clara, CA, USA). The isolated compounds and extract were dissolved in methanol at the concentration of 1 and $3 \mathrm{mg} / \mathrm{mL}$, respectively. They were filtered through Millipore $0.20 \mu \mathrm{m}$ filters before injection for chromatographic separation (Millex-LG, Tokyo, Japan). Then, $5 \mu \mathrm{L}$ of each was injected and the flow rate was $0.4 \mathrm{~mL} / \mathrm{min}$. The separation was performed on YMC triart-C18 column $(4.6 \times 150 \mathrm{~mm}, 5 \mu \mathrm{m}),\left(\mathrm{YMC}\right.$ Company, Kyoto, Japan) at $40^{\circ} \mathrm{C}$ with the gradient system of $0.1 \%$ formic acid in water (solvent $\mathrm{A}$ ) and $0.1 \%$ formic acid in methanol (solvent B) as follows 0-2 $\mathrm{min}, 20 \% \mathrm{~B} ; 2-22 \mathrm{~min}, 20-100 \% \mathrm{~B} ; 22-30 \mathrm{~min}, 100 \% \mathrm{~B}$, finally the $\mathrm{B}$ content was reduced to the initial conditions in $5 \mathrm{~min}$ and the column was re-equilibrated for $5 \mathrm{~min}$. The diode array detector (DAD) was measured over the rage of $200-600 \mathrm{~nm}$. The evaporation temperature of the ELSD detector was set at $80^{\circ} \mathrm{C}$. The nebulizer temperature of the ELSD detector was set at $30^{\circ} \mathrm{C}$.

\subsection{Analysis of the Acetone Extract by LC-DAD-MS/qTOF}

The powered E. phaseoloides leaves (100 mg) was extracted by sonication with $15 \mathrm{~mL}$ of acetone for $60 \mathrm{~min}$ at $50{ }^{\circ} \mathrm{C}$. The extracted solution was filtered and then evaporated under reduced pressure. The acetone extract was prepared in methanol to concentration $500 \mathrm{ppm}$, it was filtered twice through Millipore $0.20 \mu \mathrm{m}$ PTFE filters (Millex-LG, Tokyo, Japan). The experiments were performed on an Agilent 1290 Series UPLC system equipped with a 1290 photodiode array detector (DAD) (Agilent Technologies, Santa Clara, CA, USA) coupled to an Agilent 6545 q-TOF hybrid mass spectrometer (MS) with a dual electrospray ionization (ESI) source for simultaneous spraying of a mass reference solution that enabled continuous calibration of detected $m / z$ values was used for the analysis of the samples. The column was a Poroshell 120 EC-C18 $(2.1 \times 100 \mathrm{~mm}, 2.7 \mu \mathrm{m})$, Agilent Technologies, Santa Clara, CA, USA). The gradient system of $0.1 \%$ formic acid in water (solvent A) and $0.1 \%$ formic acid in acetonitrile (solvent B) as follows $0-20 \mathrm{~min}, 10-95 \% \mathrm{~B} ; 20-25 \mathrm{~min}, 95 \%$ B. The time for re-equilibration to initial conditions was $5 \mathrm{~min}$.

\subsection{Cell Culture}

Human spontaneously transformed keratinocytes $\mathrm{HaCaT}$ cells were cultured in Dulbecco's Modified Eagle's medium High Glucose (DMEM, purchased from Wako, Osaka, Japan). The 10\% heat-inactivated fetal bovine serum (FBS, purchased from Wako, Osaka, Japan) and antibiotics $100 \mathrm{U} / \mathrm{mL}$ penicillin-streptomycin (Wako, Osaka, Japan) were added to the medium. The cells were grown at $37{ }^{\circ} \mathrm{C}$ in $5 \% \mathrm{CO}_{2}$ humidified incubator.

\subsection{Cell Viability Measurement by MTT Assay}

HaCaT cells were seeded into 96-well plate at a density $1 \times 10^{5}$ cells $/ \mathrm{mL}$ and were incubated overnight at $37{ }^{\circ} \mathrm{C}$ in humidified atmosphere of $5 \% \mathrm{CO}_{2}$. Then, the cells were treated with isolated compounds at various concentrations for $24 \mathrm{~h}$. Subsequently, $10 \mu \mathrm{L}$ of 3-(4,5-dimethylthiazol-2-yl)-2,5-diphenyltetrazolium bromide (MTT, purchased from Tokyo Chemical Industry, Tokyo, Japan) solution $(5 \mathrm{mg} / \mathrm{mL}$ in phosphate buffered saline, PBS) was added to each well and incubated for additional $4 \mathrm{~h}$. Then, supernatant was 
discarded, and $40 \mathrm{mM} \mathrm{HCl}$-isopropanol $(100 \mu \mathrm{L})$ was added to dissolve formazan crystals. The absorbance was measured at $570 \mathrm{~nm}$ using microplate reader. The percentage of cell viability measured in control cells treated with DMSO without samples was used to calculate cell viability.

\subsection{UVB-Irradiation}

$\mathrm{HaCaT}$ cells were seeded into a 96-well plate for $24 \mathrm{~h}$ and then pre-treatment with the testing compounds at various concentrations for $24 \mathrm{~h}$ at $37^{\circ} \mathrm{C}$ in $5 \% \mathrm{CO}_{2}$ humidified incubator. The cells were washed with phosphate buffered saline (PBS) one time and added $100 \mu \mathrm{L}$ of PBS. After that, UVB-irradiation was exposed to HaCaT cells (30, 50, and $100 \mathrm{~mJ} / \mathrm{cm}^{2}$ ). UVB-irradiation was performed with Bio-Link Crosslinker (Vilber Loubert Biolink $^{\mathrm{TM}}$ BLX UVB, Cedex, France). UVB radiation source was a fluorescent lamp that emitted an energy peak at $312 \mathrm{~nm}$. After removed PBS, serum-free DMEM was added into cells and were incubated for $24 \mathrm{~h}$. Cell viability was evaluated by MTT assay.

\subsection{Wound Healing Assay}

The wound-healing assay was used to determine $\mathrm{HaCaT}$ cell migration. The HaCaT cells were seeded at a density of $1 \times 10^{5}$ cells $/ \mathrm{mL}$ on a 24 -well plate and incubated overnight at $37^{\circ} \mathrm{C}$ in a humidified atmosphere of $5 \% \mathrm{CO}_{2}$. The cells were then pre-treated for $24 \mathrm{~h}$ with samples at a concentration $100 \mu \mathrm{M}$. After that, the cell monolayer was formed, and the cells were scratched with a micropipette tip to create a wound gap. The cells were then washed with PBS and replaced by $100 \mu \mathrm{L}$ of PBS. UVB-irradiation was irradiated to $\mathrm{HaCaT}$ cells at a dose $30 \mathrm{~mJ} / \mathrm{cm}^{2}$. After removing PBS, the growth medium containing $100 \mu \mathrm{M}$ of samples was added to cells. The cells were photographed at 0 and $24 \mathrm{~h}$ using inverted microscope (Leica DM IL LED, $\times 10$ magnification). The wounding closure of $\mathrm{HaCaT}$ keratinocytes at 0 and $24 \mathrm{~h}$ after UVB-irradiation was analyzed using ImageJ. The wound area of cells was calculated based on the formula as below:

$$
\text { Wounding closure }(\%)=\frac{A_{t 0}-A_{t 24}}{A_{t 0}} \times 100
$$

$\mathrm{A}_{\mathrm{t} 0}$ is wound area measured at $0 \mathrm{~h}$ after UVB-irradiation, $\mathrm{A}_{\mathrm{t} 24}$ is wound area measured at $24 \mathrm{~h}$ after UVB-irradiation.

\subsection{Real-Time Quantitative PCR}

$\mathrm{HaCaT}$ cells $\left(1 \times 10^{5}\right.$ cells $\left./ \mathrm{mL}\right)$ were pre-treated with $2, \mathbf{4}$, and $\mathbf{1 1}(25,50$, and $100 \mu \mathrm{M})$ in 24-well plates for $24 \mathrm{~h}$. UVB-irradiation was irradiated to HaCaT cells at dose $30 \mathrm{~mJ} / \mathrm{cm}^{2}$ and then incubated $24 \mathrm{~h}$. The RNeasy Mini kit (Qiagen, Hilden, Germany) was used to extract total RNA from cells according to the manufacturer's instructions. ReverTra Ace qPCR RT Mster Mix with gDNA Remover (TOYOBO, Osaka, Japan) was used to synthesize cDNA from the extracted total RNA. Real-Time quantitative PCR was performed using the synthesized cDNA as a template with an AriaMX (Agilent Technologies, Santa Clara, CA, USA). Using the THUNDERBIRD SYBR qPCRMix (TOYOBO, Osaka, Japan) for the real-time qPCR reaction. The real-time qPCR reaction conditions were initial denaturation at $95^{\circ} \mathrm{C}$ for $60 \mathrm{~s}$. cDNA samples were amplified for 40 cycles $\left(95^{\circ} \mathrm{C}\right.$ for $15 \mathrm{~s}$ and $60{ }^{\circ} \mathrm{C}$ for $60 \mathrm{~s})$. The samples tested in three replicate and COX-2, and iNOS gene expression levels were normalized to the corresponding GADPH level. The primer sequences are shown in Table 1. 
Table 1. PCR primer sequences used in this study.

\begin{tabular}{|c|c|c|}
\hline \multirow{2}{*}{ Target } & \multicolumn{2}{|c|}{ Sequence } \\
\hline & Forward & Reverse \\
\hline GADPH & 5'-GCACCGTCAAGGCTGAGAAC-3' & 5'-ATGGTGGTGAAGACGCCAGT-3' \\
\hline COX-2 & 5'-AAGTTGGCAGCAAATTGAGCA-3' & 5'-TCCTTTTCTCCTGTGAAGGCG-3' \\
\hline iNOS & 5'-TACTCCACCAACAATGGCAA-3' & 5'-ATAGCGGATGAGCTGAGCAT- $3^{\prime}$ \\
\hline
\end{tabular}

\subsection{Statistical Analysis}

All experiments were performed in triplicate $(n=3)$ and data are expressed as mean values and standard deviation. A $p$-value of ${ }^{*} p<0.01 ; * * p<0.05$ was considered statistically significance.

\section{Results and Discussion}

\subsection{Identification of the Isolated Compounds}

Eleven compounds were identified or proposed in AE as shown in Figures 1 and 2 and Table 2, identifications of the peaks were based on the retention characteristics, UV, and the accurate mass values, as well as comparisons with the reference standard compounds and the literature. Among these compounds, gallic acid, protocatechuic acid, 4-hydroxybenzoic acid, epicatechin, luteolin-7-O- $\beta$-D-glucoside, luteolin, quercetin, dihydrokaempferol, apigenin, and kaempferol were confirmed by comparison with authentic standard.

\begin{tabular}{|c|c|c|c|c|}
\hline & & $\mathrm{R}_{1}$ & $\mathrm{R}_{2}$ & $\mathrm{R}_{3}$ \\
\hline & Gallic acid (1) & $\mathrm{OH}$ & $\mathrm{OH}$ & $\mathrm{OH}$ \\
\hline & Protocatechuic acid (2) & $\mathrm{OH}$ & $\mathrm{OH}$ & $\mathrm{H}$ \\
\hline & 4-Hydroxybenzoic acid (3) & $\mathrm{H}$ & $\mathrm{OH}$ & $\mathrm{H}$ \\
\hline
\end{tabular}

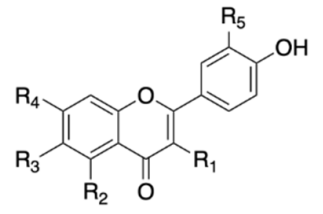

\begin{tabular}{rlllll} 
& $\mathrm{R}_{1}$ & $\mathrm{R}_{2}$ & $\mathrm{R}_{3}$ & $\mathrm{R}_{4}$ & $\mathrm{R}_{5}$ \\
\cline { 2 - 6 } Luteolin-7-O- $\beta$-D-glucoside (5) & $\mathrm{H}$ & $\mathrm{OH}$ & $\mathrm{H}$ & $\mathrm{O}-\mathrm{Glc}$ & $\mathrm{OH}$ \\
Cirsimaritin (6) & $\mathrm{H}$ & $\mathrm{OH}$ & $\mathrm{OCH}_{3}$ & $\mathrm{OCH}_{3}$ & $\mathrm{H}$ \\
Luteolin (7) & $\mathrm{H}$ & $\mathrm{OH}$ & $\mathrm{H}$ & $\mathrm{OH}$ & $\mathrm{OH}$ \\
Quercetin (8) & $\mathrm{OH}$ & $\mathrm{OH}$ & $\mathrm{H}$ & $\mathrm{OH}$ & $\mathrm{OH}$ \\
Apigenin (10) & $\mathrm{H}$ & $\mathrm{OH}$ & $\mathrm{H}$ & $\mathrm{OH}$ & $\mathrm{H}$ \\
Kaempferol (11) & $\mathrm{OH}$ & $\mathrm{OH}$ & $\mathrm{H}$ & $\mathrm{OH}$ & $\mathrm{H}$
\end{tabular}<smiles>O=C1c2c(O)cc(O)cc2OC(c2ccc(O)c(O)c2)C1O</smiles>

Epicatechin (4)<smiles>O=C1c2c(O)cc(O)cc2O[C@H](c2ccc(O)cc2)C1O</smiles>

Dihydrokaempferol (9)

Figure 1. Chemical structures of isolated and/or standard compounds from AE. 


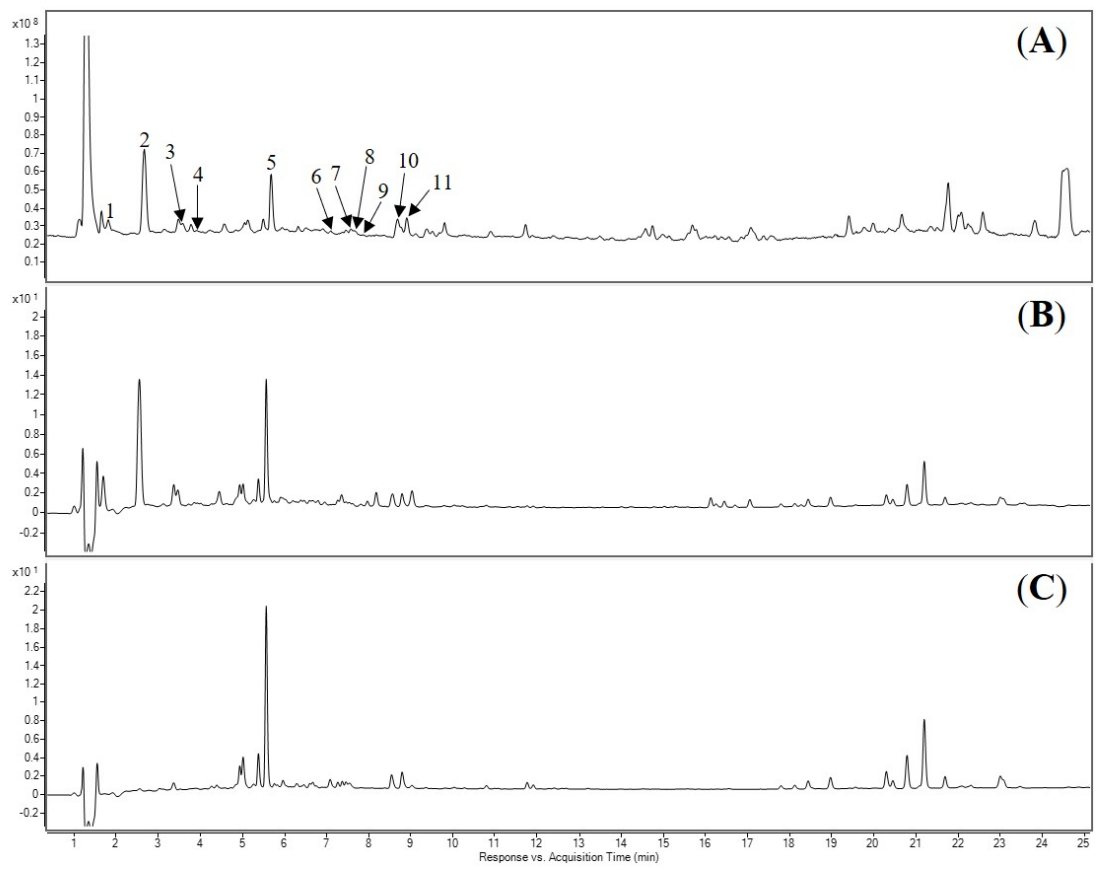

Figure 2. LC-DAD-MS chromatograms of the acetone extract of E. phaseoloides leaves. (A) Total ion chromatogram (TIC) spectrum. (B) Detected at $280 \mathrm{~nm}$. (C) Detected at $330 \mathrm{~nm}$. The numbering and identification of the peaks refer to Table 2.

Table 2. Characterization of the isolated and/or standard compounds from AE by LC-DAD-MS/qTOF.

\begin{tabular}{|c|c|c|c|c|c|c|}
\hline Peak No. & Retention Time, $t_{R}(\min )$ & Formula & {$[\mathbf{M}-\mathbf{H}]^{-}(m / z \exp )$} & Extract Mass & Error (ppm) & Identification \\
\hline 1 & 1.80 & $\mathrm{C}_{7} \mathrm{H}_{6} \mathrm{O}_{5}$ & 169.0142 & 170.0215 & -0.19 & Gallic acid \\
\hline 2 & 2.67 & $\mathrm{C}_{7} \mathrm{H}_{6} \mathrm{O}_{4}$ & 153.0199 & 154.0271 & 4.04 & Protocatechuic acid \\
\hline 3 & 3.57 & $\mathrm{C}_{7} \mathrm{H}_{6} \mathrm{O}_{3}$ & 137.0243 & 138.0322 & -0.9 & 4-Hydroxybenzoic acid \\
\hline 4 & 3.90 & $\mathrm{C}_{15} \mathrm{H}_{14} \mathrm{O}_{6}$ & 289.0734 & 290.0795 & 5.29 & Epicatechin \\
\hline 5 & 5.69 & $\mathrm{C}_{21} \mathrm{H}_{20} \mathrm{O}_{11}$ & 447.0941 & 448.1011 & 1.71 & Luteolin-7-O- $\beta$-D-glucoside \\
\hline 6 & 7.27 & $\mathrm{C}_{17} \mathrm{H}_{14} \mathrm{O}_{6}$ & 313.0716 & 314.0790 & -0.26 & Cirsimaritin \\
\hline 7 & 7.57 & $\mathrm{C}_{15} \mathrm{H}_{10} \mathrm{O}_{6}$ & 285.0408 & 286.0477 & 1.24 & Luteolin \\
\hline 8 & 7.65 & $\mathrm{C}_{15} \mathrm{H}_{10} \mathrm{O}_{7}$ & 301.0358 & 302.0432 & 0.68 & Quercetin \\
\hline 9 & 7.92 & $\mathrm{C}_{15} \mathrm{H}_{12} \mathrm{O}_{6}$ & 287.0567 & 288.2500 & -1.55 & Dihydrokaempferol \\
\hline 10 & 8.65 & $\mathrm{C}_{15} \mathrm{H}_{10} \mathrm{O}_{5}$ & 269.0459 & 270.0533 & 0.78 & Apigenin \\
\hline 11 & 8.90 & $\mathrm{C}_{15} \mathrm{H}_{10} \mathrm{O}_{6}$ & 285.0408 & 286.0477 & 1.24 & Kaempferol \\
\hline
\end{tabular}

The AE was separated by chromatographic techniques to effort known six compounds (Figure 1). On the basis of NMR, MS data, and comparing with those previously reported, the compounds were identified as protocatechuic acid (2) [11], 4-hydroxybenzoic acid (3) [12], cirsimaritin (6) [13], and dihydrokaempferol (9) [14]. The structure of luteolin-7$O$ - $\beta$-D-glucoside (5) [15] and apigenin (10) [16] were elucidated by comparing LC-ESI-MS,

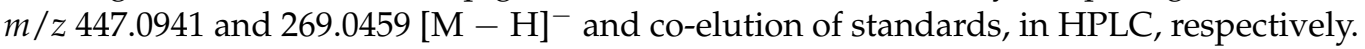

\subsection{Cytotoxicity of Isolated/Standard Compounds}

The effect of isolated compounds on normal HaCaT cells viabilities were performed by using MTT assay. Cytotoxicity of isolated compounds from AE on HaCaT cells was measured by MTT after the treatment $24 \mathrm{~h}$. The results showed that 7 and $\mathbf{1 0}(100 \mu \mathrm{M})$ have toxicity while all other compounds displayed no toxicity (Figure 3). 


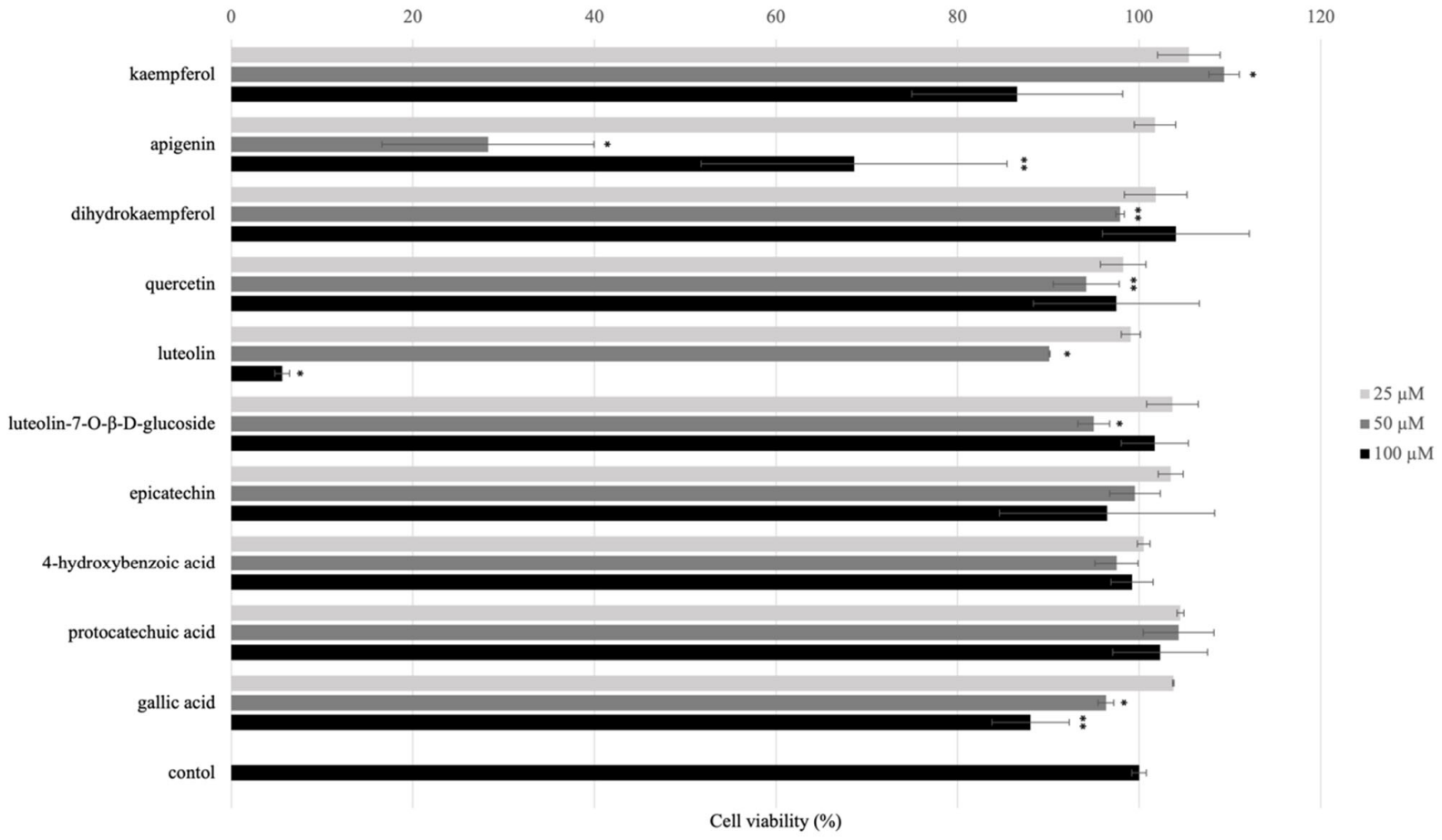

Figure 3. Effect of isolated and/or standard compounds on viability of the HaCaT cells. Cell viability was measured by MTT assay. HaCaT cells $\left(1 \times 10^{5}\right.$ cell/well $)$ were seeded to 96-well plate and then incubated overnight. The cell viability was performed after treated with isolated compounds for $24 \mathrm{~h}$. Values are presented as the mean \pm SD of three wells; ${ }^{*} p<0.01$ compared with the control group; ** $p<0.05$ compared with the control group.

\subsection{UVB-Induced HaCaT Cell Damage}

Human keratinocyte cells were irradiated with 30,50 , and $100 \mathrm{~mJ} / \mathrm{cm}^{2} \mathrm{UVB}$ and cultured with DMEM serum-free medium for $24 \mathrm{~h}$. The cell viability was measured by MTT assay. The cell viability of the 30,50 , and $100 \mathrm{~mJ} / \mathrm{cm}^{2}$ UVB-irradiated was $79.9 \%, 55.4 \%$, and $48.0 \%$, respectively (Figure 4). The result indicated that $30 \mathrm{~mJ} / \mathrm{cm}^{2}$ was a proper UVB irradiation dose for inducing decrease in cell survival of $\mathrm{HaCaT}$ cells. Thus, we decided to use $30 \mathrm{~mJ} / \mathrm{cm}^{2}$ for further experiments. 
(A)

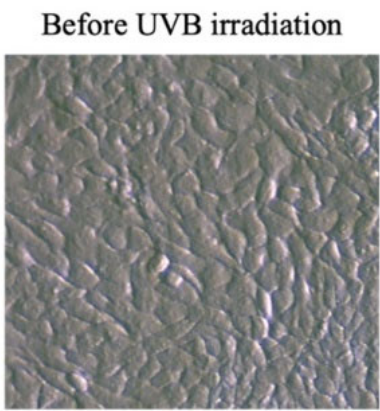

After 24 h UVB irradiation

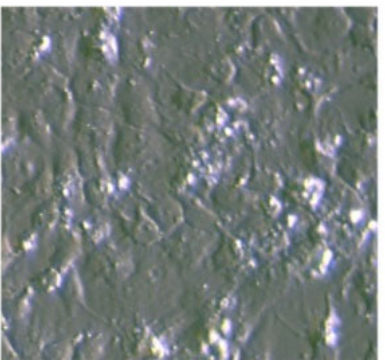

(B)

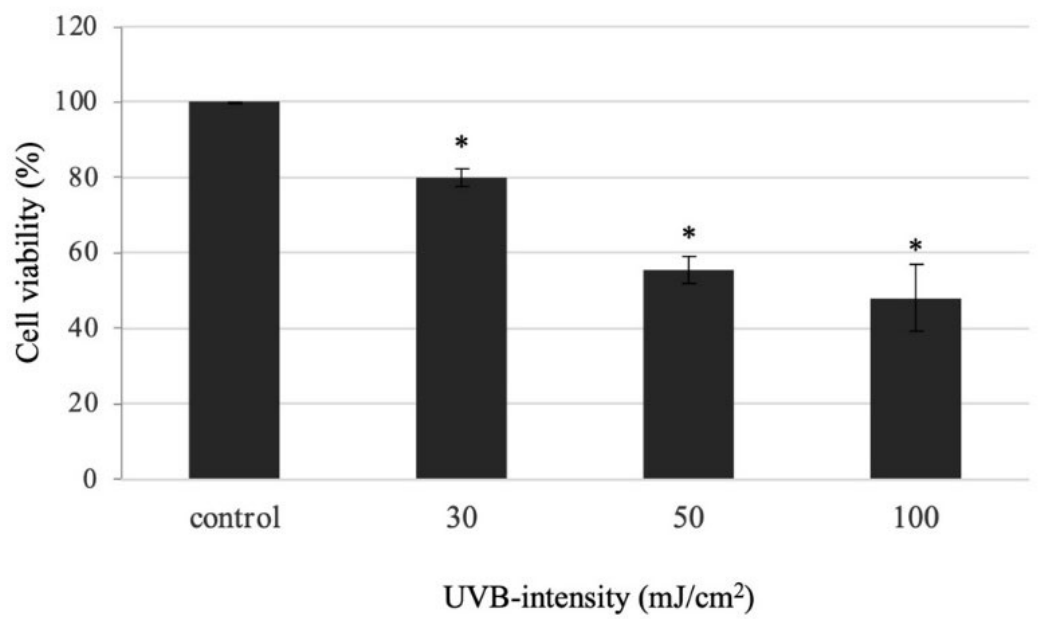

Figure 4. Effect of UVB radiation on the cell viability of HaCaT cells. (A) Morphology of HaCaT cells before and after $24 \mathrm{~h}$ UVB-irradiation $\left(30 \mathrm{~mJ} / \mathrm{cm}^{2}\right)$. (B) The cell viability in the UVB-irradiated HaCaT cells was performed using MTT assay. HaCaT cells $\left(1 \times 10^{5}\right.$ cell/well) were seeded into 96-well plate and then incubated for $24 \mathrm{~h}$. The HaCaT cells were irradiated with 30,50 , and $100 \mathrm{~mJ} / \mathrm{cm}^{2}$ of UVB. After UVB-irradiation, the HaCaT cells were incubated with DMEM serum-free medium for $24 \mathrm{~h}$. Values are presented as the mean \pm SD of three wells.; $p<0.01$ compared with the control group.

\subsection{Protective Effects of Isolated and/or Standard Compounds against UVB-Irradiation}

We determined the UVB protection effects of isolated and/or standard compounds with different concentrations 25, 50, and $100 \mu \mathrm{M}$. As shown in Figure 5, the cell viability pretreated with isolated and/or standard compounds compared with UVB-group indicated that pre-treatment with 25,50 , and $100 \mu \mathrm{M}$ of $\mathbf{2}, \mathbf{4}$, and $\mathbf{1 1}$ for $24 \mathrm{~h}$ promoted cell viability. Based on these results, pre-treatment with 25,50 , and $100 \mu \mathrm{M}$ of 2, 4, and 11 were used for RT-qPCR.

Flavonoids have a chemical structure that consist of a benzene ring (A) condensed with a six-member ring (C) that has a phenyl ring (B) as substituent in the 2-position (Figure 6A). Flavonoids are divided into six group based on the substitution pattern of ring $\mathrm{C}$. In the classification, both the oxidation state of the heterocyclic ring and the position of ring $\mathrm{B}$ are relevant (Figure 6B).

Based on the previous studies, 5, 7-OH substituents on the A-ring are needed for flavonoids to have good anti-inflammatory activity [17]. The distinction between luteolin (7), apigenin (10), and kaempferol (11) is the position of the hydroxyl group on the $C$ ring. At a concentration of $100 \mu \mathrm{M}$, kaempferol (11) outperforms luteolin (7), and apigenin (10) in protecting UVB-induced HaCaT cells. According to the results, kaempferol (11) and quercetin (8) both have 5,7-OH substituents on the A ring, with the number and position of hydroxyl groups on the B ring differing. Kaempferol (11) having only one hydroxyl group on the $\mathrm{C}$ ring have significantly increased their activity. 


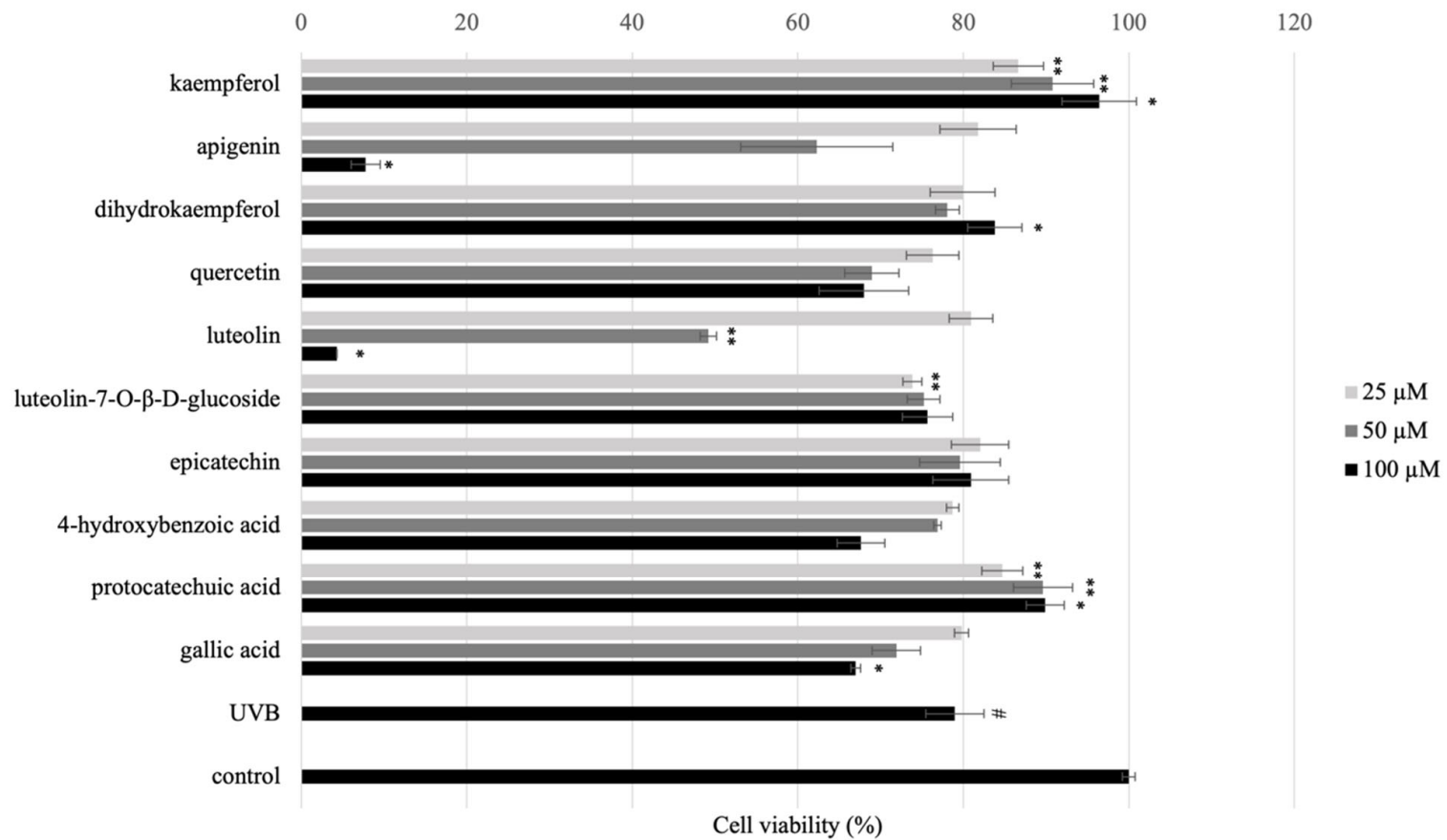

Figure 5. Phototoxicity of the pre-treatment of isolated and/or standard compounds in HaCaT cells $\left(1 \times 10^{5}\right.$ cells $\left./ \mathrm{mL}\right)$ with concentrations 25,50 , and $100 \mu \mathrm{M}$. After $24 \mathrm{~h}$, UVB $\left(30 \mathrm{~mJ} / \mathrm{cm}^{2}\right)$ was irradiated, and the cells were cultured in serum-free medium for $24 \mathrm{~h}$. The cell viability was performed by MTT assay. The data are expressed as mean $\pm \mathrm{SD}$ of at least three independent experiments in each group; $\# p \leq 0.01$, compared with the non-treated control; ${ }^{*} p<0.01$; ${ }^{* *} p<0.05$ compared with the UV control group.

(A)<smiles>O=c1cc(-c2ccccc2)oc2ccccc12</smiles>

(B)<smiles>O=c1cc(-c2ccccc2)oc2ccccc12</smiles><smiles>O=c1c(O)c(-c2ccccc2)oc2ccccc12</smiles><smiles>O=C1CC(c2ccccc2)Oc2ccccc21</smiles>

flavone

flavonol

flavanone<smiles>O=C(/C=C/c1ccccc1)c1ccccc1</smiles><smiles></smiles><smiles>O=c1c(-c2ccccc2)coc2ccccc12</smiles>

chalcone

anthocyanin

isoflavone

Figure 6. Chemical structure of flavonoid (A) general chemical structure (B) main structures classed of flavonoids.

3.5. Protocatechuic Acid, Epicatechin, and Kaempferol Rescue UVB-Induced Migration Defect in HaCaT Cells

HaCaT cell migration is critical for skin wound healing. The effect of 2, 4, and 11 on keratinocyte migration was assessed using an in vitro HaCaT cell scratch assay. After wounding, at 0 and $24 \mathrm{~h}$ the wound area surrounded by the edges of the wound monolayer 
was measured and expressed. Wounds pre-treated with $100 \mu \mathrm{M}$ of 2 and 4 had a narrow region than wounds that had not been pre-treated (Figure 7A). Additionally, wound area with of 2, 4, and 11 showed percentage differences after $24 \mathrm{~h}$ incubation (Figure 6B). The findings revealed that (-)-epicatechin, and protocatechuic acid helped to reverse the effects of UVB on wound healing.

(A)

$0 \mathrm{~h}$

$24 \mathrm{~h}$

(B)
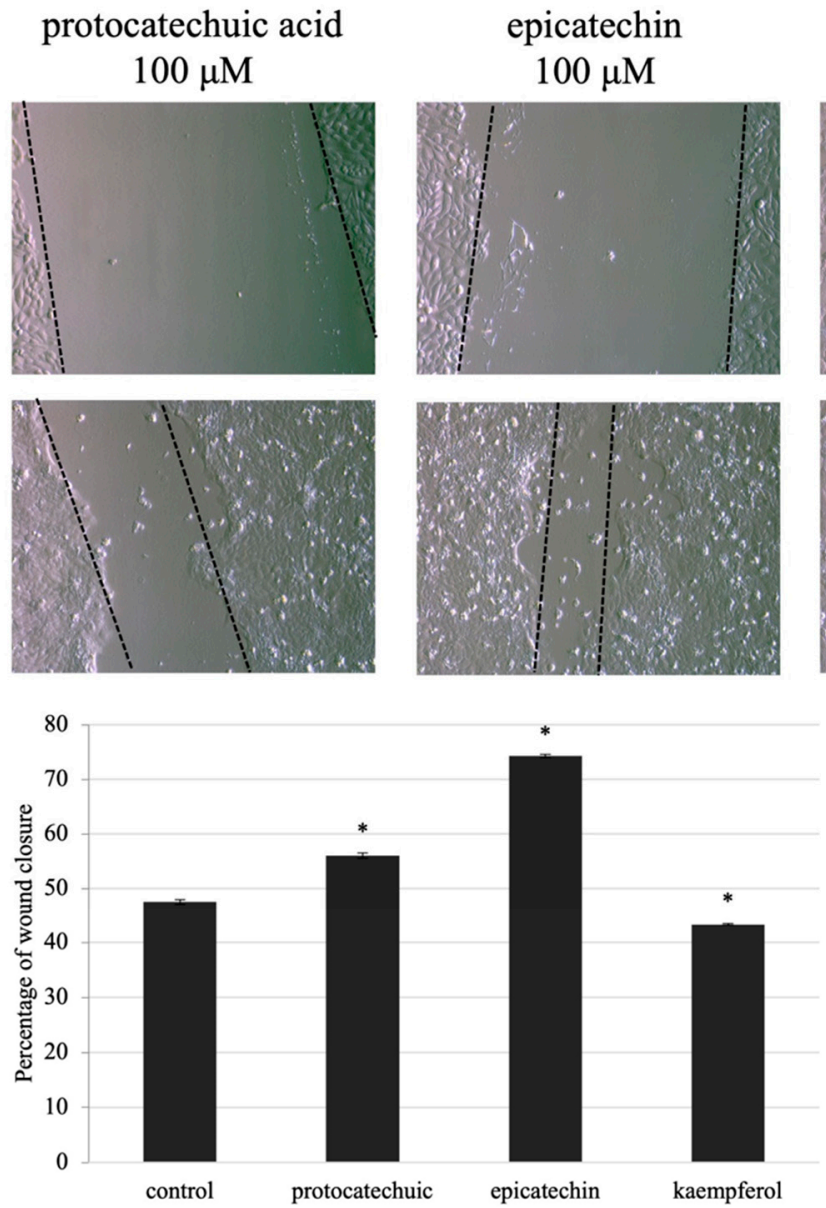

Figure 7. UVB-induced defect in HaCaT cells migration is decreased by protocatechuic acid (2), epicatechin (4), and kaempferol (11) pre-treatment. (A) Wound areas were formed in confluent layers of untreated and treated HaCaT cells prior to UVB irradiation. Phase-contrast images of the wounds were captured 0 and $24 \mathrm{~h}$ following irradiation. (B) The percentage of cell migration indicates the wound area at 0 and $24 \mathrm{~h}$ after making wound area and UVB-induced, compared with the initial area at $0 \mathrm{~h}$. Values are presented as the mean $\pm \mathrm{SD}$ of three wells.; ${ }^{*} p<0.01$ compared with the control group.

3.6. Effect of Protocatechuic Acid, Epicatechin, and Kaempferol on UVB-Irradiated Inflammatory Marker in HaCaT Cells

COX-2 and iNOS are the remarkable inflammatory markers, and over expression of these markers inhibited HaCaT cells growth and differentiation. RT-qPCR was used to examine COX-2 and iNOS expression. UVB irradiation increased the expression of COX-2 and iNOS markers in $\mathrm{HaCaT}$ cells in the current investigation. Meanwhile, pre-treatment of $100 \mu \mathrm{M}$ of 2, 4, and 11 show diminished expression of both COX-2 and iNOS in HaCaT cells. This was shown in Figure 8A,B. The results show downregulation of COX-2 and iNOS in UVB-irradiated human keratinocytes. 
(A)

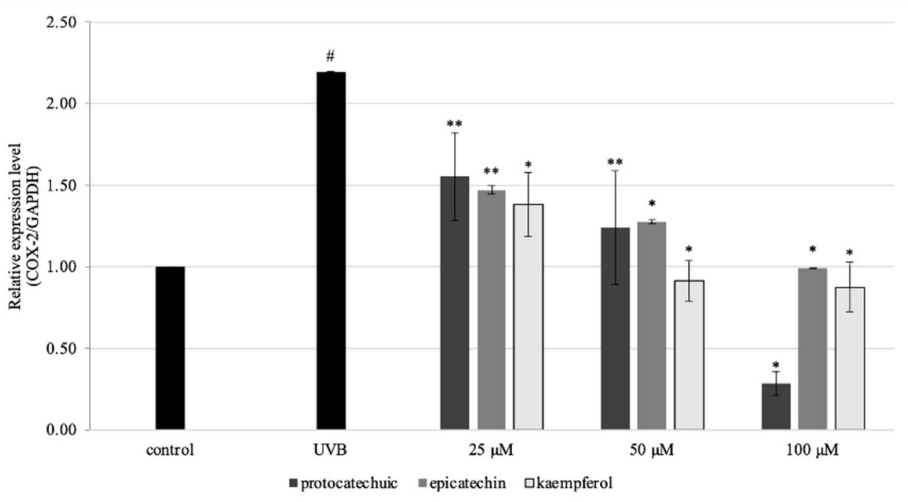

(B)

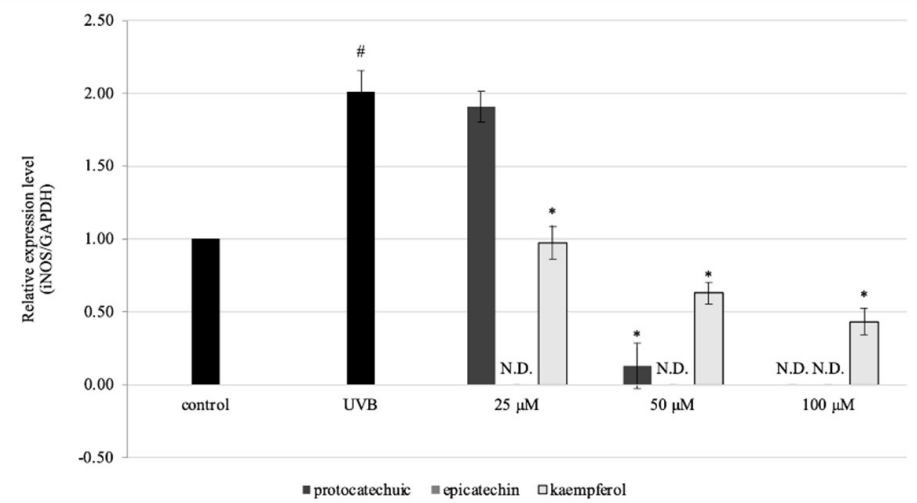

Figure 8. Effects of protocatechuic acid (2), epicatechin (4), and kaempferol (11) on the gene expression of HaCaT cells. Cells were pre-treated with 25,50 , and $100 \mu \mathrm{M}$ for $24 \mathrm{~h}$. After that, UVB $\left(30 \mathrm{~mJ} / \mathrm{cm}^{2}\right)$ were exposed to monolayer HaCaT cells. After removed PBS, serum-free DMEM was added into cells and were incubated for $24 \mathrm{~h}$. The gene expression was measured by RT-qPCR. (A) the gene expression level of COX-2, and (B) iNOS. The data are expressed as mean \pm SD of at least three independent experiments in each group; $\# p<0.01$, compared with the non-treated control; * $p<0.01$; ** $p<0.05$ compared with the UV control group.

The UV percentage of sunlight is responsible for skin damage, which occurs as a result of delicate and long-term exposure. Acute UVB irradiation of human skin causes a variety of cellular and pathological changes, including cell-cycle arrest, DNA damage, antioxidant defense system fatigue, and inflammation. Natural substances have captivated significant thought as skin protection in this regard [18]. UVB irradiation arbitrated inflammatory in this investigation, while the isolated and/or standard chemicals from AE prevented this.

COX-2 expression caused by UVB is linked to skin redness, the creation of proinflammatory cytokines, and the penetration of inflammatory cells. UVB irradiation increased iNOS expression and generation of its reactive product in HaCaT cells [19], which were successfully protected by pre-treatment with $100 \mu \mathrm{M}$ of $\mathbf{2}, \mathbf{4}$, and $\mathbf{1 1}$. Under normal circumstances, NO plays an important role in maintaining the homeostasis of normal skin function; nevertheless, excess NO production caused by increased iNOS has been linked to skin diseases such as redness, dermatosis, and psoriasis [20].

\section{Conclusions}

In conclusion, we investigate the effect of isolated and/or standard compounds from AE on anti-phototoxicity in human keratinocytes (HaCaT cells). Protocatechuic acid (2), epicatechin (4), and kaempferol (11) from AE showed that the inhibition of UVB-induced inflammation, which includes the improved expression of COX-2 and iNOS gene. Moreover, protocatechuic acid (2) and epicatechin (4) could potently enhance cell migration during wound closure. We suggest that protocatechuic acid (2), epicatechin (4), and kaempferol (11) are potential compounds for treating photoaging. 


\begin{abstract}
Author Contributions: Conceptualization, Y.M. and K.S.; methodology, Y.M. and K.S.; formal analysis, Y.M., Y.A., M.N., M.M. and D.W.; investigation, K.S.; resources, K.S.; data curation, Y.M. and K.S.; writing—original draft preparation, Y.M.; writing—review and editing, Y.M. and K.S.; supervision, K.S.; project administration, K.S.; funding acquisition, K.S. All authors have read and agreed to the published version of the manuscript.
\end{abstract}

Funding: This research received on external funding.

Institutional Review Board Statement: Not applicable.

Informed Consent Statement: Not applicable.

Data Availability Statement: Not applicable.

Acknowledgments: The first authors are thankful to the Mitsubishi UFJ Trust Scholarship Foundation for a scholarship.

Conflicts of Interest: The authors declare no conflict of interest.

Sample Availability: Samples of the compounds are not available from the authors.

\title{
References
}

1. Barua, C.C.; Buragohain, L.; Rizavi, H.; Gogoi, S.B.; Rahman, R.; Siva, B.; Mounika, K.; Babu, K.S.; Pathak, D.C.; Phukan, A. Effect of seeds of Entada phaseoloides on chronic restrain stress in mice. J. Ayurveda Integr. Med. 2020, 11, 464-470. [CrossRef] [PubMed]

2. Ikegami, F.; Sekine, T.; Duangteraprecha, S.; Matsushita, N.; Matsuda, N.; Ruangrungsi, N.; Murakoshi, I.; Entadamide, C. A sulphur-containing amide from Entada phaseoloides. Phytochemistry 1988, 28, 881-882. [CrossRef]

3. Sugimoto, S.; Matsunami, K.; Otsuka, H. Biological activity of Entada phaseoloides and Entada rheedei. J. Nat. Med. 2018, 72, 12-19. [CrossRef] [PubMed]

4. Mauriz, J.L.; Collado, P.S.; Veneroso, C.; Reiter, J.R.; González-Gallego, J. A review of the molecular aspects of melatonin's anti-inflammatory actions: Recent insights and new perspectives. J. Pineal Res. 2013, 54, 1-14. [CrossRef] [PubMed]

5. Marabini, L.; Melzi, G.; Lolli, F.; Dell'Agli, M.; Piazza, S.; Sangiovanni, E.; Marinovich, M. Effects of Vitis vinifera L. leaves extract on UV radiation damage in human keratinocytes (HaCaT). J. Photochem. Photobiol. B Biol. 2020, 204, 111810-111817. [CrossRef] [PubMed]

6. Sitailo, L.A.; Tibudan, S.S.; Denning, M.F. Activation of caspase-9 is required for UV-induced apoptosis of human keratinocytes. J. Biol. Chem. 2002, 277, 19346-19352. [CrossRef] [PubMed]

7. Zhu, X.; Li, N.; Wang, Y.; Ding, L.; Chen, H.; Yu, Y.; Shi, X. Protective effects of quercetin on UVB irradiation-induced cytotoxicity through ROS clearance in keratinocyte cells. Oncol. Rep. 2017, 37, 209-218. [CrossRef] [PubMed]

8. Wang, L.; Oh, J.Y.; Kim, Y.S.; Lee, H.G.; Lee, J.S.; Jeon, Y.J. Anti-photoaging and Anti-Melanogenesis Effects of Fucoidan Isolated from Hizikia fusiforme and Its Underlying Mechanisms. Mar. Drugs 2020, 18, 427. [CrossRef] [PubMed]

9. Sobeh, M.; El-Raey, M.; Rezq, S.; Abdelfattah, M.A.; Petruk, G.; Osman, S.; El-Shazly, A.M.; El-Beshbishy, H.A.; Mahmoud, M.F.; Wink, M. Chemical profiling of secondary metabolites of Eugenia uniflora and their antioxidant, anti-inflammatory, pain killing and anti-diabetic activities: A comprehensive approach. J. Ethnopharmacol. 2019, 240, 111939-111950. [CrossRef] [PubMed]

10. Sobeh, M.; Petruk, G.; Osman, S.; El Raey, M.A.; Imbimbo, P.; Monti, D.M.; Wink, M. Isolation of myricitrin and 3, 5-di-O-methyl gossypetin from Syzygium samarangense and evaluation of their involvement in protecting keratinocytes against oxidative stress via activation of the Nrf-2 pathway. Molecules 2019, 24, 1839. [CrossRef] [PubMed]

11. Okba, M.M.; El Awdan, S.A.E.; Yousif, M.F.; El Deeb, K.S.; Soliman, F.M. Entada rheedii seeds thioamides, phenolics, and saponins and its antiulcerogenic and antimicrobial activities. J. Appl. Pharm. Sci. 2018, 8, 101-108.

12. Cho, J.Y.; Moon, J.H.; Seong, K.Y.; Park, K.H. Antimicrobial Activity of 4-Hydroxybenzoic Acid and trans 4-Hydroxycinnamic Acid Isolated and Identified from Rice Hull. Biosci. Biotechol. Biochem. 1998, 62, 2273-2276. [CrossRef] [PubMed]

13. Jibril, S.; Sirat, H.M.; Basar, N. Bioassay-Guided Isolation of Antioxidants and $\alpha$-Glucosidase Inhibitors from the Root of Cassia sieberiana D.C. (Fabaceae). Rec. Nat. Prod. 2017, 11, 406-410.

14. Ragasa, C.Y.; Pendon, Z.; Sngalang, V.; Rideout, J.A. Antimicrobial Flavones from Coleus amboinicuc. Philipp. J. Sci. 1999, 128, 347-351.

15. Qian, Z.M.; Li, H.J.; Ping, L.; Rena, M.T.; Tang, D. Simultaneous Qualitation and Quantification of Thirteen Bioactive Compounds in Flos Lonicerae by High-Performance Liquid Chromatography with Diode Array Detector and Mass Spectrometry. Biol. Pharm. Bull. 2007, 55, 1073-1076. [CrossRef] [PubMed]

16. Liu, W.; Kong, Y.; Zu, Y.; Fu, Y.; Luo, M.; Zhang, L. Determination and quantification of active phenolic compounds in pigeon pea leaves and its medicinal product using liquid chromatography-tandem mass spectrometry. J. Chromatogr. A 2010, 1217, 4723-4731. [CrossRef] [PubMed]

17. Wang, X.; Cao, Y.; Chen, S.; Lin, J.; Bian, J.; Huang, D. Anti-inflammation Activity of Flavones and Their Structure-Activity Relationship. J. Agric. Food Chem. 2021, 69, 7285-7302. [CrossRef] [PubMed] 
18. Park, J.; Woo, Y.; Cho, H. Regulation of Anti-Oxidative, Anti-Inflammatory, and Anti-Apoptotic Activity of Advanced Cooling Composition (ACC) in UVB-Irradiated Human HaCaT Keratinocytes. Int. J. Mol. Sci. 2020, 21, 6527. [CrossRef] [PubMed]

19. Song, X.; Bi, Z.; Xu, A. Green tea polyphenol epigallocatechin-3-gallate inhibits the expression of nitric oxide synthase and generation of nitric oxide induced by ultraviolet B in HaCaT cells. Chin. Med. J. 2006, 119, 282-287. [CrossRef] [PubMed]

20. Chen, F.; Tang, Y.; Sun, Y.; Veeraraghavan, V.P.; Mohan, S.K.; Cui, C. 6-shogaol, a active constiuents of ginger prevent UVB radiation mediated inflammation and oxidative stress through modulating NrF2 signaling in human epidermal keratinocytes (HaCaT cells). J. Photochem. Photobiol. B Biol. 2019, 197, 11518-11524. [CrossRef] [PubMed] 